Review

\title{
Genetic and Molecular Genetic Basis of Nuclear-Plastid Incompatibilities
}

\author{
Vera S. Bogdanova
}

Institute of Cytology and Genetics, Siberian Branch of Russian Academy of Sciences, Novosibirsk 630090, Russia; vera@bionet.nsc.ru

Received: 18 October 2019; Accepted: 20 December 2019; Published: 23 December 2019

check for updates

\begin{abstract}
Genetic analysis of nuclear-cytoplasm incompatibilities is not straightforward and requires an elaborated experimental design. A number of species have been genetically studied, but notable advances in genetic mapping of nuclear loci involved in nuclear-plastid incompatibility have been achieved only in wheat and pea. This review focuses on the study of the genetic background underlying nuclear-plastid incompatibilities, including cases where the molecular genetic basis of such incompatibility has been unveiled, such as in tobacco, Oenothera, pea, and wheat.
\end{abstract}

Keywords: cytonuclear incompatibility; genetic analysis; plastids

\section{Introduction}

Nuclear-cytoplasmic incompatibility, also referred to as cytonuclear incompatibility, is generally accepted to be an important evolutionary factor [1] that contributes to the establishment of reproductive isolation [2]. Apart from its fundamental evolutionary role, reproductive isolation of diverged plant species and subspecies has a strong impact on breeders' efforts, since more or less, distant wild relatives of cultivated plants are frequently recruited to improve the existing crops $[3,4]$. This approach to plant breeding and related studies have mostly been directed to improve crop yield, resistance to various pathogens, or adaptation to unfavorable climatic changes [5]. The development of molecular methods has favored introgression of certain genes, extended genetic blocks from wild species, or traditional landraces into cultivars [6,7]. The first experience of wide hybridization of crops with their wild relatives faced problems of hybrid incompatibility, including hybrid sterility, hybrid breakdown, and genetic linkage of loci responsible for desirable and undesirable traits [5]. In some plants, the genetic basis of hybrid incompatibility has been studied (reviewed in [8-11]). A large number of cases have been reported where the decreased fitness of hybrids was related to impaired functions of mitochondria or plastids $[8,12,13]$. Here, we review the cases where genetic analyses have been undertaken to uncover the genetic background of incompatibility of the nucleus with plastids and its molecular genetic mechanisms.

\section{Occurrence of Nuclear-Plastid Incompatibility}

A comprehensive list of the registered cases of nuclear-plastid incompatibilities is presented in [12] and includes representatives of 14 plant genera. However, in most cases, studying nuclear-plastid incompatibility results in a mere affirmation that incompatibility exists, with systematic studies carried out for only a limited number of genera. For example, nuclear-chloroplast incompatibility was genetically studied in interspecific hybrids of Oenothera L. [14-21], Zantedeschia Spreng. [22,23], and Passiflora L. [24].

Nuclear-plastid conflict was thoroughly described in a somewhat artificial system, intergeneric cybrids (somatic cell hybrids) of Solanaceae [25-34]. In this case molecular basis of the conflict has been dissected (see below). 
In Pisum L., some intraspecific crosses involving representatives of cultivated and wild subspecies have resulted in hybrids with abnormal leaf development, variegated chlorosis [35], and abnormalities in meiosis, resulting in partial fertility of pollen and ovuli [36] which was attributed to nuclear-plastid incompatibility $[37,38]$. This case has been subjected to extensive genetic and molecular genetic analysis.

Nuclear-plastid incompatibilities were also revealed in the hybrids resulting from crosses of phylogeographic lineages within a species of the herbs Silene nutans L. [39] and Campanulastrum americanum (L.) Small $[1,40]$.

In Triticum L., cytoplasmic effects in the course of backcrossing have been studied for a long time [41]. One of the most frequent manifestations of the alien cytoplasm was male sterility [42,43], while other effects included variegated leaf pigmentation [44], pistillody, germless grain formation, haploid and tween seedling formation, depressed growth vigor, premature sprouting, delayed heading [42], and decreased plant stature [45,46]. It was not always clear which cellular compartment was responsible for such an effect, mitochondria, plastids, or both [47-50]. This case deserves attention due to the thorough genetic and molecular genetic analyses performed in the study.

\section{Genetic Analysis of Nuclear-Plastid Incompatibility}

\subsection{Genetic Analysis of Nuclear-Plastid Incompatibility in Barrel Medic}

Asymmetry in the phenotypes of progeny was observed in hybrids obtained in reciprocal crosses of two Israeli local forms of Medicago truncatula Gaertn. When the dusky green race (Du) originating from Jawniel was pollinated by the bright green race (Br) from Mt. Tabor, the hybrids had pale or very pale cotyledons, with leaves that manifested all levels of subnormal green pigmentation, from almost colorless to normal green. Plants with pale and green sectors were met. Seed fertility was low, with two to three seeds per pod as compared with eight to nine seeds in parental lines. The reciprocal $\mathrm{F}_{1}$ hybrids had light-green cotyledons. New leaves were pale but during the growth acquired healthy green coloration, but the seed set was poor, with two to three seeds per pod. In the hybrids, where dusty green race was maternal, chlorophyll content was 2.5 times lower than in reciprocals, and it was lower in both types of hybrids as compared with both parental lines [51]. The results of segregation in $\mathrm{F}_{2}$ were confusing, no clear ratios of phenotypes varying in a wide range of chlorophyll abnormalities could be traced. The variability of the segregation ratios is explained by taking into account biparental mode of chloroplast inheritance in $M$. truncatula which was shown later [52]. Test cross $\mathrm{Br} \times(\mathrm{Du} \times \mathrm{Br})$ produced two types of progeny, with green cotyledons and green leaves (22 plants) and with light-green cotyledons and pale leaves (31 plants) [51], which does not contradicts the 1:1 ratio, and therefore can be interpreted as monogenic segregation. In the reciprocal cross $(\mathrm{Du} \times \mathrm{Br}) \times \mathrm{Br}$, the progenies suffered from a more severe plastid dysfunction; they were scarce, producing in total 17 plants, of which 10 had light-green leaves and the rest had pale leaves [51]. This also does not contradict the 1:1 ratio and can be interpreted as segregation of alleles of one nuclear gene. However, until the origin of the plastids in the crosses is clearly established, the study's [51] inferences should be considered with care.

Another plastid disorder observed in these crosses manifested as a fine mosaic of green, pale, or yellowish tissue variegation. In crosses with the $\mathrm{Br}$ line, green and variegated $\mathrm{F}_{2}$ progenies segregated at a ratio close to 3:1 which indicated involvement of one nuclear factor [53]. However, this analysis was done only in the background of the presumable Br cytoplasm, and therefore the relevance of this nuclear factor to cytonuclear compatibility remains unclear.

\subsection{Genetic Analysis of Nuclear-Plastid Incompatibility in Tan Wattles}

Crosses were made of two species of tan wattles, green (Acacia decurrens Willd.) and black (A. mollissima Willd.) with a goal to produce hybrids of economic value. The hybrids were of little commercial importance but produced some data on the occurrence of chlorotics in the offsprings [54]. Upon cross-pollination in both reciprocal directions, $F_{1}$ hybrids were formed that had low fertility and various degree of chlorosis. During growth, normal bluish-green coloration was restored 
which hampered classification of chlorotic versus normal phenotype. In the $\mathrm{F}_{2}$ generation, chlorophyll pigmentation varied widely, from white and very pale green to green and bluish-green. Clear Mendelian ratios were not observed, possibly due to uncertainties in phenotypic classification. Thus, the data on $\mathrm{F}_{2}$ segregation did not contribute to drawing conclusions on the genetic basis of the hybrid chlorosis. Therefore, backcrosses were made, where $F_{1}$ hybrids with the cytoplasm from green wattle were pollinated with green or black wattle. After pollination with black wattle, the majority of progenies had normal chlorophyll pigmentation, although some chlorotics could be observed. Unexpectantly, after pollination with green wattle, phenotypic segregation was observed, resembling that in $\mathrm{F}_{2}$. The proportion of mosaics was high at about $37 \%$, in spite of the same origin of the cytoplasm and pollen. It was concluded that the genome of green wattle contained some genetic factor(s) that caused instability of chlorophyll pigmentation (appearance of mosaics) as a result of improper interaction of nuclear alleles from green and black wattles [55]. This conclusion, again, should be considered with care until the source of cellular organelles is established with certainty.

\subsection{Genetic Analysis of Nuclear-Plastid Incompatibility in Evening Primroses}

In Oenothera, crosses were made to study the genetic bases of hybrid chlorosis occurring in incompatible combinations of certain types of nuclear and plastid genomes. Nuclear genomes met in related species of Oenothera were classified into three types, A, B, and C, while plastid genomes (plastomes) were classified into five types, I-V [14]. Various combinations of the genome variant and plastomes were found to have different degrees of compatibility.

In Oenothera atrovirens Shull \& Bartlett (genome C, plastome IV), the nuclear gene Fl determines stem shape, while two lor loci affect the leaf width. Brought into other cytoplasm type by crosses, lor lor plants displayed strong chlorophyll deficiency; $F l F l$ plants were weak and pale, and the combination lor lor $\mathrm{Fl} \mathrm{Fl}$ caused embryonic lethality. In the presence of the native atrovirense plastids (situation of heteroplasmy), such homozygotes were pale brownish plants and died early [56]. In Oenothera, homologous recombination and free segregation of chromosomes due to permanent translocation heterozygosity are generally suppressed [57], thus, the $F l$ and lor visible alleles marked the chromosome arms carrying loci of cytonuclear compatibility.

Hybridization between species with genome A and plastome I, Oenothera hookeri Torr. et A. Gray or O. elata Kunth and species O. argillicola Mack. with genome C and plastome V, resulted in formation of heterozygotes for the genomes A and C and plastids from both parents (as typical for Oenothera). Such hybrids from both reciprocal crosses suffered from severe chlorosis and died at the seedling stage due to incompatibility of the genome $\mathrm{A}$ with the plastome $\mathrm{V}$ and of the genome $\mathrm{C}$ with the plastome I. For this reason, it was impossible to obtain $\mathrm{F}_{2}$ from such crosses. This difficulty was overcome by developing an intermediate, a substitution line of $O$. argillicola which carried plastome IV instead of the plastome V [58], characterized by wide compatibility. When this line was crossed with O. elata, the resulting hybrids were heterozygous for the genomes $\mathrm{A}$ and $\mathrm{C}$ and carried plastids from both parents. Plant sectors carrying plastome IV were green, whereas sectors carrying plastome I were chlorotic but formed flowers that were used for subsequent test crosses. In such a manner, progeny was obtained of the backcross A, C $\times$ A, A in the background of the plastome I [59]. The progenies were classified into normal or chlorotic, and cytological analysis of meiocytes was employed to determine which of the chromosomes from the complement $C$ were associated with the chlorotic phenotype. In the heterozygote for genomes $A$ and $C$, reciprocal translocations resulted in formation of six-chromosome rings, four-chromosome rings, and free bivalents in prophase of meiosis. These were passed to the progeny in different combinations that could be determined cytologically. It was concluded that the presence of individual foreign chromosomes did not cause chlorosis, while their various combinations brought about different degrees of chlorosis. The stronger degree of chlorosis was associated with a higher number of foreign chromosomes in a hybrid genome, that is, the responsible nuclear factors were scattered all over the genome. Similar results were obtained in another cross 
designed to estimate the effect of the chromosome complement $A$ on the compatibility with the plastome $\mathrm{V}, \mathrm{A}, \mathrm{C} \times \mathrm{C}, \mathrm{C}$ in the background of plastome $\mathrm{V}$ [59].

Genetic analysis was carried out for the incompatibility of genome A with plastome III, which was manifested as chlorophyll deficiency normalized in the course of plant growth (virescent phenotype), which made it possible to obtain and study segregation ratios in the progeny. A cross was made between O. elata (genome A) and O. grandiflora L. Hér. ex Aiton. (genome B), and both parental lines carried the same plastome III transferred by repeated crosses from O. glazioviana Micheli. Among the $F_{2}$ plants, some had normal green pigmentation, while others had chlorophyll deficiency of varying degrees. Unfortunately, the exact ratio of green and non-green plants could not be established due to the difficulties of classification, but it was clear that at least two nuclear factors segregated in the $\mathrm{F}_{2}$ population which generated incompatible nuclear-plastid combinations. Analysis of a large number of molecular markers placed one of these factors onto the genetic map of the chromosome 4 and the other-onto the chromosome 7 [60].

\subsection{Genetic Analysis of Nuclear-Plastid Incompatibility in Calla Lilies}

In an ornamental plant Zantedeschia, nuclear-cytoplasmic conflict occurs upon crossing of an evergreen species Z. aethiopica (L.) Spreng. (AE) with representatives of the winter-dormant species group, in particular, Z. odorata P.L. Perry (OD). In $\mathrm{F}_{1}$ hybrids from reciprocal crosses, OD plastids were associated with albino phenotype, and AE plastids brought about virescent plants [22]. To study the genetic basis of the incompatibility, segregation ratios were analyzed in $\mathrm{F}_{2}$ and in backcrosses. In the $\mathrm{F}_{2}$ population resulting from the cross $\mathrm{AE} \times \mathrm{OD}$, green, virescent, and albino plants appeared, although in $F_{1}$, all plants were virescent, which was evidence that segregation of nuclear genes was involved into the incompatibility. It was difficult to distinguish between green and virescent plants, while albino plants, which could only be maintained via embryo culture [61], comprised 18 of 58 germinated embryos. Green plants were rare, and the authors concluded that the nuclear-plastid conflict in Zantedeschia was mediated by at least two nuclear genes [23], although the proposed model did not explain the proportion of albino plants. At the same time, the hypothesis of one nuclear gene cannot be discarded. The ratio 18:58 in $\mathrm{F}_{2}$ does not contradict 1:4 expected for segregation of one recessive allele. However, the segregation ratio in backcrosses was contradictory; there appeared a large number of albino plants in the background of the own cytoplasm. This could be attributed to nuclear-nuclear interaction, but the results should be treated with care because of possible paternal leakage of chloroplasts.

\subsection{Genetic Analysis of Nuclear-Plastid Incompatibility in Azaleas}

In intersubgeneric crosses of evergreen (EV) azaleas of the genus Rhododendron L. with yellow-flowered deciduous azalea R. japonicum (A. Gray) Kron f. flavum (JP), unilateral genome-plastome incompatibility occurred in $F_{1}$ progenies when EV plants were used as seed parent. The majority of the progenies suffered from albinism because of incompatibility between EV-plastids and JP nuclear genome, and green plants occurred only in the case of occasional plastid DNA inheritance from the JP-parent [62]. Crossing of diploids, $2 \times \mathrm{EV}$ (genome constitution EE) $\times 2$ $\times \mathrm{JP}$ (genome constitution JJ) produced albinas with genomic constitution EJ. Crosses were made of azaleas of different ploidy, $4 \times \mathrm{EV} \times 4 \times \mathrm{JP}$ and $2 \times \mathrm{EV} \times 4 \times \mathrm{JP}$, that gave progenies with genomic constitution EEJJ and EJJ, respectively. All of the progenies manifested nuclear-plastid incompatibility. This indicated that the JP nuclear genome carried dominant factor(s) that restricted development of EV chloroplasts. At the same time, plants with genomic constitution EEJ, resulting from the cross $4 \times \mathrm{EV} \times$ $2 \times \mathrm{JP}$, were green, although they carried maternally-inherited EV plastids, and were not rescued by occasional leakage of paternal chloroplasts. Thus, incompatibility of EV plastids with JP genome could be compensated by increasing the EV dosage in the nuclear genome in the offspring [63]. 


\subsection{Genetic Analysis of Nuclear-Plastid Incompatibility in Cereals}

In Triticeae, nuclear-cytoplasmic conflict (apart from cytoplasmic male sterility) has been known for a long time, although it was not always clear which cytoplasmic component was responsible for the incompatibility [41]. However, here, we discuss this case in detail because it has been profoundly genetically studied.

Incompatibility of some Triticum species with the cytoplasm of Ae. tauschii Coss. [45] (the authors used the name Ae. squarrosa L.) and Ae. longissima Schweinf. et Muschl. [64] has been genetically studied.

A series of alloplasmic lines was obtained which combined Ae. taushii cytoplasm with nuclear genomes of different representatives of Dinkel wheat (genome composition AABBDD), Emmer group (genome composition AABB), and Timopheevii group (genome composition AAGG) [45]. After six generations of backcrossing with the pollen of hexaploid wheats (AABBDD), fertile alloplasmic lines were obtained with a normal chromosome configuration (21 bivalents) void of observable morphologic or physiologic irregularities. When wheats of the Emmer group (AABB) were used as the recurrent parent, all alloplasmic lines with the Ae. tauschii cytoplasm carried one additional chromosome. This indicates that some genetic factor(s) located in the additional chromosome were required for compatibility of nuclear genomes with the cytoplasm. Sporophytes and male gametophytes without the additional chromosome died. An analysis of a set of Chinese Spring alloplasmic mono-trisomic lines, in which one of the chromosomes of the complement $\mathrm{D}$ was substituted by a homoeologous chromosome from the A or B complement, led to a conclusion that factor(s) responsible for the compatibility of the nucleus and the cytoplasm were located on the chromosome 1D. Equivalent nuclear factor(s) providing compatibility with the Ae. tauschii cytoplasm were also present in the genome of tetraploid wheats of the Timopheevii group (AAGG) [45].

The additional 1D chromosome providing compatibility of tetraploid genomes of the AABB type with the cytoplasm of Ae. tauschii can be transmitted or not transmitted via female gametes (not following Mendelian ratios). As a result, when alloplasmic lines were pollinated by the recurrent parent lacking the additional chromosome, the resulting seeds segregated into viable (carrying $1 \mathrm{D}$ chromosome, $2 n=29,3 n=44$ ) and abortive (lacking $1 \mathrm{D}$ chromosome, $2 n=28,3 n=42$ ). In some cases, viable but shriveled seeds formed that produced miniature plants which developed severe chlorophyll variegation under low temperatures. The lines which brought about formation of abortive seeds, when used as pollen parents, were referred to as type I and classified as incompatible with the cytoplasm of Ae. tauschii. The lines which brought about shriveled but viable seeds were classified as partially compatible with the cytoplasm of Ae. tauschii and referred to as type III. Type II, which was fully compatible with the cytoplasm of Ae. tauschii, was represented by the wheats from the Timopheevii group.

The existence of the miniature plants that survived without the additional chromosome allowed for performing genetic analysis. The miniature and weak plants with or without chlorophyll variegation appeared in the progeny of crosses with partially compatible lines. Analysis of the number of progenies in phenotypic classes according to chlorophyll variegation and plant vigor allowed the authors to propose segregation of two nuclear genes. They concluded that one of the nuclear genes, denoted as $C p$, was involved into an interaction with chloroplasts; it had allelic state $C p 1$ in incompatible lines and allelic state $C p 2$ in partially compatible lines. The homozygotes $C p 1 C p 1$ died resulting in abortive seeds, the heterozygotes $C p 1 C p 2$ were manifested as shriveled seeds that grew into variegated plants, and the homozygotes $\mathrm{Cp} 2 \mathrm{Cp} 2$ had normal chlorophyll pigmentation. The second nuclear gene was supposed to be related to plant vigor and was denoted as Cv. It had allelic state Cv1 in incompatible lines and allelic state $C v 2$ in partially compatible lines. The homozygotes $C v 1 C v 1$ were miniature, the heterozygotes $\mathrm{Cv} 1 \mathrm{Cv} 2$ were weak plants if they lacked chlorophyll variegation (in homozygotes $C p 2$ Cp2) or miniature plants if they suffered chlorophyll variegation (heterozygotes $C p 1 C p 2$ ), and the homozygotes Cv2 Cv2 were of subnormal plant vigor [45].

Genetic analysis was performed on the factor(s) conferring compatibility of the T. timopheevii (Zhuk.) Zhuk. genome with the cytoplasm of Ae. tauschii which was denoted as Ncc-tmp (from 
nucleus-cytoplasm compatibility-timopheevii) and possibly corresponded to the Cp3 allele (described by Ohtsuka $[45,65]$. This factor was introgressed into T. durum Desf. cv. Langdon by a series of backcrosses with the pollen of $\mathrm{cv}$. Langdon in the background of the Ae. tauschii cytoplasm. Since the additional chromosome 1D was absent, the introgressed line retained the Ncc-tmp factor indispensable for formation of viable seeds.

The RAPD (random amplified polymorphic DNA) markers were developed which were linked to the compatibility factor Ncc-tmp proceeding from T. timopheevii Zhuk. [65]. Southern blotting was used to determine which of the chromosomes carried Ncc-tmp in a series of disomic lines where one of the chromosomes of the A or B complement was substituted by the homoeologous D chromosome. It was shown that a specific signal disappeared from the genome of T. durum cv. Langdon along with the substitution of the $1 \mathrm{~A}$ chromosome with 1D. Thus, Ncc-tmp factor was associated with the chromosome $1 \mathrm{~A}$ and denoted Ncc-tmp1A [66].

A number of test crosses were made to determine whether additional compatibility factors were present in the G genome of T. timopheevii $[66,67]$. Hybrids were obtained of T. timopheevii with T. durum in the background of the cytoplasm of Ae. tauschii. After a test cross, segregation of the compatible and incompatible alleles was estimated by the ratio of plump and shriveled seeds. If the initial line input one dominant allele into the heterozygote used for the test cross, the expected segregation ratio was 1:1. If the initial line contributed two dominant compatible alleles, from A genome and G genome, the possible input of such heterozygote into the offspring could be one of the following four options: One dominant allele from genome A, one dominant allele from genome $\mathrm{G}$, both dominant alleles, or neither of compatible alleles. The first three options, unlike the fourth, should result in formation of viable seeds, therefore, the expected segregation ratio was 3:1, although some deviations were possible since chromosomes from the $G$ genome were not always transmitted. Segregation analysis in the progeny of a number of test crosses showed that the $G$ genome of T. timopheevii contained a functional allele of nuclear-cytoplasm compatibility, which was denoted as Ncc-tmp1G [67].

Southern blot hybridization, of DNA clones mapped on homoeologous group I using RAPD markers and linked to Ncc-tmp $1 A$ as a probe, showed that this locus's position is close to the centromere of the chromosome 1A [67]. Such a location of compatibility factors appears to be conservative in the cereals. For example, a DNA fragment from the centromeric region of the rye $1 \mathrm{R}$ chromosome seemed to contain genetic factor, conferring compatibility of the genome of the bread wheat (cv. Chinese Spring) with rye cytoplasm Secale cereale L. in a substitution line [68]. Chromosomes from the homoeologous group 1 restored plant vigor and male fertility in alloplasmic wheat with Agropyron Gaertn. [69] and Elymus L. [70] cytoplasm.

Another series of experiments [71,72] performed genetic analysis of the factors conferring compatibility of the genomes of tetraploid wheats with the cytoplasm of Aegilops longissima. Similar to the case of Ae. tauschii, a compatible line of T. turgidum was obtained by introgression of the compatible allele of a locus denoted as scs (species cytoplasm specific) from T. timopheevii. In the presence of the introgressed allele, $s c s{ }^{t i}$, viable seeds were formed; however, male gametophytes were inviable [71]. Restoration of male fertility required introgression of the compatible allele of another locus denoted as $\mathrm{Vi}$ (vitality) [72]. The compatible $\mathrm{Vi}$ allele appeared to arise by a spontaneous mutation in an alloplasmic line of T. aestivum with the cytoplasm of Ae. cylindrica Host [73].

Segregation for scs and $V i$ alleles was analyzed with the use of RFLP-markers (restriction fragment length polymorphism). The $V i$ locus was positioned in the distal part of the chromosome arm 1BS, and scs locus, in the chromosome arm 1AL close to the centromere [64], almost at the same location as independently introgressed Ncc-tmp $1 A$ [66]. It is highly possible that Ncc-tmp $1 A$ conferring compatibility of the nuclear genome of T. turgidum with the cytoplasm of Ae. tauschii, and scs ${ }^{t i}$ conferring compatibility with the cytoplasm of Ae. longissima, correspond to the same locus [67].

A more precise mapping of the $s c s{ }^{t i}$ was made in the cross of euplasmic lines with the cytoplasm of durum wheat. One of the parent lines was homozygous for the introgressed $s c s{ }^{t i}$ allele from T. timopheevii. The resulting $\mathrm{F}_{2}$ progenies were genotyped by test crosses as pollen parents with 
a tester line having the cytoplasm from Ae. longissima and one copy of the allele $s c{ }^{t i}$. $\mathrm{F}_{2}$ plants possessing two functional copies of $s c s^{t i}$ upon crossing gave only plump viable seeds; plants with one functional copy of $\operatorname{scs}^{t i}$ (hetero-, or possibly hemizygotes) segregated with the ratio of 3:1 of plump to shriveled unviable seeds, and plants lacking functional copy of $s c{ }^{t i}$ gave the segregation ratio of 1:1 of plump to shriveled seeds. In all plants, the allelic state of a number of RFLP, AFLP (amplified fragment length polymorphism), and microsatellite markers was scored. On the basis of the segregation data, a genetic map of the centromeric region of the $1 \mathrm{AL}$ chromosome arm was constructed. Microsatellite markers flanking the scs locus, Xbcd12 and Xbcd1449-1A.2, were mapped at a distance of 2.3 and $0.6 \mathrm{cM}$, respectively [46]. Later, the mapping population was extended to comprise 2158 plants, additional molecular markers were developed, and a more detailed genetic map was constructed of the chromosome 1 A region. The markers nearest to scs ${ }^{t i}$, Xwmc120 and Xtc252572-2- $a$, were mapped at a distance of 0.52 and $0.61 \mathrm{cM}$, respectively [74].

The genetic factor conferring compatibility of the 1D chromosome of hexaploid wheat with the cytoplasm of Ae. longissima was denoted as $s c s^{a e}$ and mapped using the radiation hybrid method in 1DL chromosome arm [75]. An alloplasmic line of T. turgidum was used, in which a part of 1A chromosome was substituted with an almost entire 1D chromosome from T. aestivum [76]. Under impact of radiation, chromosomes were disrupted, and some chromosome fragments were lost. To compensate for the loss of chromosome matter, plants grown from irradiated seeds were crossed with the euplasmic line of T. turgidum (genome constitution AABB), to obtain heterozygotes (so-called radiation hybrids), in which deleterious effect of the breaks of chromosomes from $A$ and $B$ genomes was compensated by the presence of intact chromosomes. But the additional 1D chromosome turned out to be hemizygous, so that the breaks in this chromosome were not compensated. The loss of some chromosome portions caused by irradiation was determined by analysis of molecular markers specific for 1D. Since scs ae allele is indispensable for compatibility with the cytoplasm of Ae. longissima it was inevitably present in all viable plants. Eight molecular markers covering a stretch of about $8.3 \mathrm{Mb}$ that were constantly present in radiation hybrids determined the position of the scs locus on the chromosome arm 1DL [75]. Later, additional markers were involved in radiation hybrid mapping. In the plants grown from the irradiated seeds, the allelic state of the scs locus was determined by crossing followed by segregation analysis of the seed phenotype (plump vs. shriveled). In addition, the presence or absence of the 1D-specific markers was scored. As a result, the approximate length of the 1D chromosome stretch containing scs ${ }^{a e}$ was shortened to $1.1 \mathrm{Mb}$. On the basis of the synteny of the genomes of wheat, rice, sorghum, and Brachypodium P.Beauv., 16 genes were predicted to be located in this region [77].

\subsection{Genetic Analysis of Nuclear-Plastid Incompatibility in Peas}

In pea, one accession of wild subspecies (VIR320) was found to be associated with a severe impairment of plastid function when used as a cytoplasm donor in crosses with the cultivated material [35,37,38]. The occurrence of the incompatibility at the intraspecies level facilitated hybridologic analysis. However, direct segregation ratio count was impossible, since $\mathrm{F}_{1}$ hybrids produced only a few seeds or none at all.

To study the genetic basis of the nuclear-plastid incompatibility in pea, a mapping population of recombinant inbred lines (RIL) was established based on a cross of a tester line carrying a number of visible markers with the wild line VIR320 [78]. The allelic state of compatibility loci of the plants from the RIL population was determined by crosses in which pollen of the tested plants was applied to the pistils of VIR320 as a donor of poorly compatible plastids. Nuclear-cytoplasm combination was regarded as incompatible if all of its carriers were deficient in chlorophyll pigmentation, which could vary in color from white to pale green and had reduced leaf organs. Otherwise, the combination was deemed to be compatible.

It was expected that those lines that inherited alleles of the compatibility factor(s) from the tester line would produce offspring with typical signs of nuclear-plastid incompatibility, while those carrying 
alleles of compatibility factor(s) from VIR320 would give progenies without clear signs of the plastid dysfunction. Analysis of genetic linkage using a number of visible and molecular markers led to a conclusion that a typical syndrome of nuclear-plastid incompatibility was conditioned by two unlinked nuclear loci, denoted as Scs1 and Scs2, by analogy with the earlier mentioned wheat gene. Scs1 was mapped on linkage group III, and Scs 2 was mapped on linkage group V. If both Scs loci were heterozygous, severe chlorophyll deficiency, reduction of leaves and stipules, and low-fertile pollen (33\% on average) developed in the background of the cytoplasm of the wild pea. If only one of these loci was heterozygous, the plants appeared normal, although somewhat paler than reciprocals [78].

Having established that nuclear-plastid incompatibility was conditioned by the two unlinked loci, it became possible to analyze inheritance of each of them separately, in the crosses not complicated by severe breakdown of the progeny. In a series of test crosses, it was shown that Scs1 allele from cultivated pea was lethal for sporophytes and male gametophytes in the background of the wild pea cytoplasm. Scs2 allele was not lethal, but was underrepresented among male gametophytes and sporohytes, indicating that some yet unknown genetic interactions brought about lethality to the carriers of this allele [79]. In a number of crosses, Scs1 and Scs2 loci were genetically mapped; Scs1 in an interval of about $2.5 \mathrm{cM}$ on linkage group III, and Scs2 in an interval 2.0 to $15.1 \mathrm{cM}$ varying from cross to cross on linkage group V [79].

\subsection{General Consideration on Genetic Control of Nuclear-Plastid Incompatibility}

Summary of studies made to uncover genetic basis of cytonuclear incompatibilities is given in the Table 1.

Table 1. Experimental studies to elucidate the genetic basis of nuclear-plastid incompatibility.

\begin{tabular}{|c|c|c|c|c|c|}
\hline Plant Genus & Type of Cross or Line & Experimental Approach & Observations & Conclusion & Ref \\
\hline Medicago & $\begin{array}{l}\text { Backcross of } \mathrm{F}_{1} \text { to one of } \\
\text { the parental lines in } \\
\text { reciprocal directions }\end{array}$ & $\begin{array}{l}\text { Analysis of segregation } \\
\text { ratio for chlorophyll } \\
\text { pigmentation }\end{array}$ & 1:1 segregation & Monogenic inheritance & [51] \\
\hline \multirow[t]{2}{*}{ Acacia } & $\mathrm{F}_{2}$ from interspecific cross & $\begin{array}{l}\text { Analysis of segregation } \\
\text { ratio for chlorophyll } \\
\text { pigmentation }\end{array}$ & $\begin{array}{l}\text { Lack of clear segregation } \\
\text { ratios }\end{array}$ & Inconclusive & [55] \\
\hline & $\begin{array}{l}\text { Backcross of } F_{1} \text { to parental } \\
\text { species-donor of } \\
\text { cytoplasm }\end{array}$ & $\begin{array}{l}\text { Analysis of segregation } \\
\text { ratio for chlorophyll } \\
\text { pigmentation }\end{array}$ & $\begin{array}{l}\text { Lack of clear segregation } \\
\text { ratios, high frequency of } \\
\text { mosaics }\end{array}$ & $\begin{array}{l}\text { Hybrid chlorosis assigned to } \\
\text { nuclear-nuclear interactions }\end{array}$ & [55] \\
\hline \multirow[t]{3}{*}{ Oenothera } & $\begin{array}{l}\mathrm{F}_{2} \text { from interspecific } \\
\text { crosses }\end{array}$ & $\begin{array}{l}\text { Cosegregation of visible } \\
\text { markers and chlorophyll } \\
\text { pigmentation }\end{array}$ & $\begin{array}{l}\text { Linkage of two visible } \\
\text { markers to chlorophyll } \\
\text { deficiency }\end{array}$ & $\begin{array}{c}\text { Assignment of incompatibility loci to } \\
\text { chromosome arms marked by visible } \\
\text { markers }\end{array}$ & [56] \\
\hline & $\begin{array}{l}\text { Backcross of interspecies } \\
\mathrm{F}_{1} \text { hybrid to both parental } \\
\text { species on different } \\
\text { cytoplasm backgrounds }\end{array}$ & $\begin{array}{l}\text { Cytological analysis } \\
\text { and association of certain } \\
\text { chromosomes with } \\
\text { chlorophyll deficiency }\end{array}$ & $\begin{array}{l}\text { Degree of chlorosis related } \\
\text { to the number of foreign } \\
\text { chromosomes }\end{array}$ & $\begin{array}{l}\text { Nuclear factors of incompatibility } \\
\text { scattered all over genome }\end{array}$ & [59] \\
\hline & $\mathrm{F}_{2}$ from interspecific cross & $\begin{array}{l}\text { Cosegregation of } \\
\text { molecular markers } \\
\text { and chlorophyll } \\
\text { pigmentation }\end{array}$ & $\begin{array}{l}\text { Linkage of some molecular } \\
\text { markers to chlorophyll } \\
\text { deficiency }\end{array}$ & $\begin{array}{l}\text { Segregation of at least two nuclear } \\
\text { factors of incompatibility; one on } \\
\text { chromosome } 4 \text { and the other-on } \\
\text { chromosome } 7\end{array}$ & [60] \\
\hline Zantedeschia & $\begin{array}{l}\mathrm{F}_{2} \text { from interspecific cross } \\
\text { and backcrosses }\end{array}$ & $\begin{array}{l}\text { Analysis of segregation } \\
\text { ratio for chlorophyll } \\
\text { pigmentation }\end{array}$ & $\begin{array}{l}\text { Lack of clear segregation } \\
\text { ratios }\end{array}$ & Inconclusive & [23] \\
\hline Rhododendron & $\begin{array}{l}\mathrm{F}_{1} \text { from crosses of species } \\
\text { of different ploidy }\end{array}$ & $\begin{array}{l}\text { Correspondence of } \\
\text { genome constitution } \\
\text { and chlorophyll } \\
\text { pigmentation }\end{array}$ & $\begin{array}{l}\text { dependence of chlorophyll } \\
\text { deficiency on the dosage of } \\
\text { maternal nuclear genome }\end{array}$ & $\begin{array}{l}\text { Presence of dominant } \\
\text { dosage-dependent alleles }\end{array}$ & [63] \\
\hline $\begin{array}{l}\text { Triticum } \\
\text { and Aegilops }\end{array}$ & $\begin{array}{c}\text { Alloplasmic lines on } \\
\text { background of Ae. taushii } \\
\text { cytoplasm }\end{array}$ & $\begin{array}{c}\text { Substitution of } \\
\text { individual chromosomes } \\
\text { from D genome by } \\
\text { homoeologous } \\
\text { chromosomes of A and B } \\
\text { genomes }\end{array}$ & $\begin{array}{l}\text { Invariable presence of 1D } \\
\text { chromosome in compatible } \\
\text { combinations }\end{array}$ & $\begin{array}{l}\text { Presence of compatibility factors on } \\
\text { 1D chromosome }\end{array}$ & [45] \\
\hline
\end{tabular}


Table 1. Cont.

\begin{tabular}{|c|c|c|c|c|c|}
\hline \multirow[t]{6}{*}{ Plant Genus } & Type of Cross or Line & Experimental Approach & Observations & Conclusion & Ref \\
\hline & $\begin{array}{l}\text { Backcrosses of } \mathrm{F}_{1} \text { from } \\
\text { cross of alloplasmic lines } \\
\text { on background of } A e . \\
\text { taushii cytoplasm with } \\
\text { incompatible or partially } \\
\text { compatible wheat species } \\
\text { to incompatible(partially } \\
\text { compatible) parental line }\end{array}$ & $\begin{array}{l}\text { Analysis of segregation } \\
\text { ratios for chlorophyll } \\
\text { variegation and plant } \\
\text { vigor }\end{array}$ & $\begin{array}{l}\text { Segregation ratios } \\
\text { corresponding to two-gene } \\
\text { control }\end{array}$ & $\begin{array}{l}\text { Two types of loci involved in } \\
\text { compatibility with Ae. taushii } \\
\text { cytoplasm, one interacting with } \\
\text { chloroplasts and a second related to } \\
\text { plant vigor }\end{array}$ & [45] \\
\hline & $\begin{array}{c}\text { Test crosses of alloplasmic } \\
\text { lines on background of } A e \text {. } \\
\text { taushii cytoplasm with } T \text {. } \\
\text { timopheevii }\end{array}$ & $\begin{array}{l}\text { Analysis of segregation } \\
\text { ratios for seed viability }\end{array}$ & $\begin{array}{l}\text { Segregation ratios } \\
\text { corresponding to two } \\
\text { compatible alleles }\end{array}$ & $\begin{array}{l}\text { Presence of compatibility factors on } \\
1 \mathrm{G} \text { chromosome from } T \text {. timopheevii }\end{array}$ & [67] \\
\hline & $\begin{array}{l}\text { Test cross of an alloplasmic } \\
\text { line on background of } A e \text {. } \\
\text { longissima cytoplasm with } \\
\text { near-isogenic line } \\
\text { heterozygous for } \\
\text { compatibility loci }\end{array}$ & $\begin{array}{l}\text { Cosegregation of RFLP } \\
\text { markers and traits } \\
\text { related to plant vigor } \\
\text { and seed viability, } \\
\text { Southern blot analysis }\end{array}$ & $\begin{array}{l}\text { Southern blot hybridization } \\
\text { using DNA markers linked } \\
\text { to compatibility loci }\end{array}$ & $\begin{array}{l}\text { Positioning of one compatibility locus } \\
\text { in the distal part of the chromosome } \\
\text { arm 1BS, and the second-in } \\
\text { the chromosome arm 1AL close to } \\
\text { the centromere }\end{array}$ & [64] \\
\hline & $\begin{array}{c}\mathrm{F}_{2} \text { from a cross of } \\
\text { homozygous lines, one } \\
\text { parent with introgressed } \\
\text { compatibility locus from } T \text {. } \\
\text { timopheevii }\end{array}$ & $\begin{array}{l}\text { Genotyping of } \mathrm{F}_{2} \\
\text { progenies by an } \\
\text { additional test cross }\end{array}$ & $\begin{array}{l}\text { Cosegregation of some } \\
\text { molecular markers with } \\
\text { seed viability }\end{array}$ & $\begin{array}{c}\text { Compatibility locus mapped on } \\
\text { chromosome } 1 \mathrm{~A} \text { with bordering } \\
\text { markers at a distance of } 2.3 \text { and } 0.6 \mathrm{cM}\end{array}$ & [46] \\
\hline & $\begin{array}{c}\mathrm{F}_{1} \text { from a cross of } \\
\text { irradiated alloplasmic line } \\
\text { on background of } A e . \\
\text { longissima cytoplasm } \\
\text { added with 1D } \\
\text { chromosome with } \\
\text { euplasmic line (radiation } \\
\text { hybrids) }\end{array}$ & $\begin{array}{l}\text { Presence/absence of } \\
\text { molecular markers } \\
\text { specific for 1D }\end{array}$ & $\begin{array}{l}\text { Finding of markers } \\
\text { constantly present in } \\
\text { radiation hybrids } \\
\text { compatible with } A e . \\
\text { longissima cytoplasm }\end{array}$ & $\begin{array}{c}\text { Molecular markers covering a stretch } \\
\text { of about } 8.3 \mathrm{Mb} \text { denoting position of a } \\
\text { compatibility locus on chromosome } \\
\text { arm } 1 \mathrm{DL}\end{array}$ & [75] \\
\hline Pisum & $\begin{array}{l}\text { Population of recombinant } \\
\text { inbred lines }\end{array}$ & $\begin{array}{l}\text { Genotyping of lines from } \\
\text { mapping population by } \\
\text { additional crosses to a } \\
\text { testerline with } \\
\text { incompatible cytoplasm }\end{array}$ & $\begin{array}{l}\text { Cosegregation of some } \\
\text { visible and molecular } \\
\text { markers with } \\
\text { compatibility/incompatibility }\end{array}$ & $\begin{array}{l}\text { Segregation of two nuclear loci for } \\
\text { incompatibility, one on linkage group } \\
\text { III and a second on linkage group V }\end{array}$ & {$[78,79]$} \\
\hline
\end{tabular}

The reviewed genetic studies dealt with the dominant cases of nuclear-plastid incompatibility, that is, manifested in $\mathrm{F}_{1}$, although incompatible or poorly compatible paternal alleles of the nuclear loci were present in only one copy in the heterozygous state. In these cases, one copy of the compatible maternal allele was insufficient to maintain normal chloroplast functioning. One of possible explanations is that chloroplast genes, unlike nuclear ones, exist in multiple copies, with hundreds of nucleoids per plastid and dozens of plastids per cell [80]. Plastid gene products frequently participate in formation of multisubunit complexes together with nuclear gene products, but expression levels of plastid genes, measured as the number of corresponding mRNAs, can be more than ten times higher than that of nuclear counterparts [81]. For this reason, nuclear function in heterozygote could be insufficient for maintaining a proper stoichiometry of the gene products. Notably, increasing the ploidy of a seed parent abolishes the manifestation of incompatibility [63].

\section{Molecular Genetic Analysis of Nuclear-Plastid Incompatibility}

In a few published studies, the molecular genetic bases of incompatibility of the nuclear genome and plastids has been addressed. In cybrids of Solanacea and in interspecific crosses of Oenothera, the plastid factors were postulated while the nuclear factors remained unknown. In pea, conflicting factors of both plastid and nuclear origin were nominated. In wheat, molecular genetic dissection of the nuclear factor of cytonuclear compatibility received little attention, although it is prominent in that it demonstrates the power of genetic analysis. It remains unknown whether the involved cytoplasmic factors originate from plastids, mitochondria, or both. 


\subsection{Molecular Genetic Analysis of Nuclear-Plastid Incompatibility in Solanaceae}

One of bright examples of nuclear-plastid incompatibility is represented by cybrids of Solanaceae plants obtained by a protoplast fusion and regenerated in cell culture. For example, plants with the nuclear genome of belladonna (Atropa belladonna L.) and chloroplasts of tobacco (Nicotiana tabacum L.) completely lack chlorophyll pigmentation [26]. A very elegant study of the molecular basis of incompatibility in such plants employed a genetic approach [82]. Cell cultures with an incompatible combination of nucleus (A. belladonna) and chloroplasts ( $N$. tabacum) were treated with nitrosomethylurea to induce mutations restoring normal chlorophyll pigmentation. Three independent mutations were obtained that were associated with the outgrowth of green shoots. Chloroplast transfer between cell cultures with intact nuclei showed that these mutations occurred in the tobacco plastid genome.

Earlier, the plastid genome of belladonna was sequenced, and sites potentially involved in the conflict were revealed [83]. These regions of the tobacco plastid genome were sequenced in the mutants with a restored compatibility. In the three mutants mentioned above, specific nucleotide substitutions were found, as well as a substitution common for all mutants. The latter substitution in the gene atpA, coding for alpha subunit of the ATPase, converted 264-th codon, CCC (proline), into CTC (leucine). Normally in tobacco, the cytosine base which had undergone the mutation is edited at the mRNA level and is turned into uracil, thus, converting the CCC-Pro codon into the CUC-Leu. In contrast, in belladonna, leucine is encoded by the CTC codon [83]. Thus, the identified mutation did not change the amino acid sequence of the AtpA protein but abolished the need for RNA editing. RNA-editing factors are known to be encoded in the nucleus [84,85], and apparently belladonna genome lacks the factor which specifically edits the cytosine in the 264-th codon of the atpA gene, resulting in the amino acid replacement of leucine by proline L264P [82].

\subsection{Molecular Genetic Analysis of Nuclear-Plastid Incompatibility in Evening Primroses}

As mentioned earlier, in Oenothera, three types (A, B, and C) of nuclear genomes and five types (I to $\mathrm{V}$ ) of plastid genomes (plastomes) are described that produce different compatible and incompatible combinations $[14,16]$. An attempt was made to establish the molecular determinants in these plastid genomes involved in nuclear-cytoplasm incompatibility.

The five types of the plastid genomes were sequenced [86], and variants of the nucleotide sequences were considered in relation to the patterns of compatibility and incompatibility of their carriers. If a DNA sequence variant was found in all plastomes compatible with a certain genome (for example, A), while all incompatible plastomes carried another structural element, such locus was considered as a candidate [87]. Unfortunately, interspecific variability of the plastomes turned out to be very high, and pairwise comparisons revealed thousands of differences. The comparison of compatible and incompatible plastid genomes allowed 82 candidates to be chosen, 19 of which corresponded to protein-coding loci, and 63 of which corresponded to promoter regions in intergenic spacers. Out of the promoter region-specific loci, 38 were predicted to be binding sites for PEP (plastid-encoded polymerase) RNA-polymerase and 25 predicted to be binding sites for NEP (nuclear-encoded polymerase). Participation of some of the identified genes, for example those coding for subunits of NADH dehydrogenase, in incompatibility was considered not likely, since their disruption in the tobacco plastid genome did not cause notable phenotypic change [88]; although this conclusion was argued against [89]. To narrow the candidate list, the authors [87] applied a series of rather arbitrary criteria, such as too high or too low variability. They also discarded the candidates associated with the differences not affecting functional domains or biochemical properties of the encoded proteins.

Plants of one incompatible combination were deficient in chlorophyll pigmentation and displayed a reduced activity of the photosystem II. Therefore, the authors suggested that the chloroplast factor of incompatibility of the plastome I with the genome $\mathrm{AB}$ (heterozygote for $\mathrm{A}$ and $\mathrm{B}$ ) resided in the intergenic spacer $c l p P-p s b B$. This intergenic spacer contains a 148-bp deletion which affects the promoter for the NEP polymerase of the $c l p P$ gene and a predicted promoter element for the PEP polymerase 
of the $p s b B$ gene located in two different DNA strands [87]. The nuclear factor of incompatibility remains unknown.

\subsection{Molecular Genetic Analysis of Nuclear-Plastid Incompatibility in Peas}

In order to reveal the plastid participant of the nuclear-plastid conflict in pea, five chloroplast genomes were sequenced that originated from the accessions contrasting in compatibility with the nuclear genome of cultivated pea. The study focused on a search for the plastid genes interacting with the nuclear $S c s 1$, since its effect was more pronounced and did not depend on the other nuclear loci, unlike Scs2 (see above).

The features of the primary structure that were similar in incompatible plastid genomes and different in compatible genomes were regarded as candidates responsible for nuclear-plastid compatibility. Thirty-seven such candidates were found in 14 non-coding regions and seven protein-coding loci. Changes of the protein primary structure were considered a more likely cause for incompatibility, and the range of candidates was narrowed to four protein-coding loci $(a c c D, r p o B, y c f 1$, and $y c f 2$ ).

Nuclear-cytoplasmic incompatibility is expected if nucleus- and plastid-encoded subunits of multimeric complexes poorly match each other [13]. In such a case, the most probable plastid candidate gene should have a nuclear-encoded counterpart mapped to the region of linkage group III where Scs1 was located. On the basis of the synteny of legume genomes [90], a search was made in the annotated genome of Medicago truncatula of the loci encoding proteins participating in formation of complexes with the products of selected plastid candidate genes. The genetic interval where $S c s 1$ was mapped corresponded to a stretch of $1.2 \mathrm{Mb}$ of M. truncatula chromosome 3 containing 166 annotated gene products, one of which was "biotin carboxyl carrier protein of acetyl-CoA carboxylase" (GeneID:11410363). Thus, the plastid $a c c D$ gene, coding for the beta subunit of carboxyltransferase of plastid multimeric acetyl-CoA carboxylase, was identified as a candidate gene involved in the nuclear-plastid incompatibility, and, for the first time, both nuclear and plastid participants were nominated [91]. The proposed model of incompatibility implies a failure of the protein-protein interaction in a multimeric enzyme complex of acetyl-CoA carboxylase. This model was further substantiated by genetic mapping of $S c s 2$ to a region which, in M. truncatula., harbors the AccA locus coding for alpha subunit of carboxyltransferase of acetyl-CoA carboxylase [91]. Allelic polymorphism in the candidate genes was extensively studied [92].

\subsection{Molecular Genetic Analysis of Nuclear-Plastid Incompatibility in Cereals}

Detailed genetic mapping of nucleus-cytoplasm compatibility (scs) loci on wheat chromosomes 1A and 1D (see above) facilitated the identification of the nuclear candidate gene responsible for the interaction with the cytoplasm. Bulked segregant analysis was applied, where the negative bulk contained DNA of the lines with a radiation-induced deletion of $\operatorname{scs}^{a e}$ allele, while the positive bulk contained DNA of the lines with the functional scs ${ }^{a e}$ [93]. These bulks were sequenced, and the detected SNPs allowed identifying markers which were then used to genotype a population of 644 radiation hybrid lines.

As a result, the genetic position of $s c s$ was further refined, and the physical map of a BAC clone of Ae. taushii, spanning the region of interest and comprising about $500 \mathrm{~Kb}$, was scrutinized. It turned out that the ORF representing a putative rhomboid gene was tagged by Xndsu297, the only marker cosegregating with the $s_{c s}{ }^{a e}$ phenotype. The rhomboid gene was sequenced from different sources characterized by functional and non-functional alleles of $s c s$, and it was established that, in all non-functional allelic variants, the arginine residue was replaced with lysine [93].

Rhomboids constitute a family of intramembrane cleaving proteases that are key regulators of critical cellular processes involved in the maintenance of the structural and functional integrity of mitochondria and plastids [94], although their link with the developmental processes is still missing [95]. A possible mechanism of the effect of a protease on an organelle function is exemplified by an improper 
$\mathrm{N}$-terminus processing of light harvesting proteins in alien henbane (Hyoscyamus niger L.) chloroplasts in cybrids with tobacco nucleus [96].

\section{Concluding Remarks}

The evolutionary significance of cytonuclear conflicts has been widely recognized $[8,11,13]$. Consequently, a question arises, if there exist certain genes or gene types predisposed to cause hybrid incompatibilities, thus contributing to postzygotic reproductive isolation. All the studies of plastid-nuclear incompatibility, reviewed in this review, refer to different genetic loci and may be classified according to the pathways of interaction between nuclear-encoded and organelle-encoded products as protein-RNA (Solanacea cybrids), protein-DNA (Oenothera, presumable), or protein-protein (pea, possibly wheat). The evolutionary significance of protein-protein interactions was substantiated by a number of studies. There are some plastid genes characterized by accelerated rates of nucleotide changes in some plant lineages, for example, $c l p P$ and $a c c D$ ([97] accompanied by an increase in the rate of evolution of the corresponding nuclear-encoded subunits, which was supposed to reflect antagonistic coevolution between plastids and nucleus [97]. The same situation of rapid coevolution between plastid-encoded RNA polymerase and nuclear-encoded sigma-factors [98] and plastid-and nuclear-encoded subunits of ribosomes [99] was observed in Geraniaceae. In cross-hybridizations, such rapidly evolving genes with high probability would create poorly compatible combinations and reduce the fitness of their carriers, contributing to reproductive isolation, and therefore could be referred to as "speciation genes" [9].

Regardless of the nature of cytonuclear incompatibility, the knowledge of its genetic and molecular genetic basis can help overcome the restrictions it imposes, and design breeding programs aimed at employment of natural biodiversity, to improve existing crops.

Author Contributions: Writing and editing, V.S.B. All authors have read and agreed to the published version of the manuscript.

Funding: This work was supported by the Russian State Scientific project № 0324-2019-0041 at the Institute of Cytology \& Genetics SB RAS, Novosibirsk and the project № 19-04-00162 of the Russian Fund for Fundamental Research.

Acknowledgments: The author is grateful to O.E. Kosterin for fruitful discussion.

Conflicts of Interest: The author declares no conflict of interest.

\section{References}

1. Barnard-Kubow, K.B.; So, N.; Galloway, L.F. Cytonuclear incompatibility contributes to the early stages of speciation. Evolution 2016, 70, 2752-2766. [CrossRef] [PubMed]

2. Bomblies, K. Doomed lovers: Mechanisms of isolation and incompatibility in plants. Ann. Rev. Plant Biol. 2010, 61, 109-124. [CrossRef] [PubMed]

3. Brozynska, M.; Furtado, A.; Henry, R.J. Genomics of crop wild relatives: Expanding the gene pool for crop improvement. Plant Biotechnol. J. 2016, 14, 1070-1085. [CrossRef] [PubMed]

4. Berni, R.; Cantini, C.; Romi, M.; Hausman, J.F.; Guerriero, G.; Cai, G. Agrobiotechnology goes wild: Ancient local varieties as sources of bioactives. Int. J. Mol. Sci. 2018, 19, 2248. [CrossRef]

5. Fernie, A.R.; Tadmor, Y.; Zamir, D. Natural genetic variation for improving crop quality. Curr. Opin. Plant Biol. 2006, 9, 196-202. [CrossRef]

6. McCouch, S. Diversifying selection in plant breeding. PLoS Biol. 2004, 2, e347. [CrossRef]

7. Hajjar, R.; Hodgkin, T. The use of wild relatives in crop improvement: A survey of developments over the last 20 years. Euphytica 2007, 156, 1-13. [CrossRef]

8. Johnson, N.A. Hybrid incompatibility genes: Remnants of a genomic battlefield? Trends Genet. 2010, 26, 317-325. [CrossRef]

9. Rieseberg, L.H.; Blackman, B.K. Speciation genes in plants. Ann. Bot. 2010, 106, 439-455. [CrossRef]

10. Maheshwari, S.; Barbash, D.A. The genetics of hybrid incompatibilities. Ann. Rev. Genet. 2011, 45, 331-355. [CrossRef] 
11. Fishman, L.; Sweigart, A.L. When two rights make a wrong: The evolutionary genetics of plant hybrid incompatibilities. Ann. Rev. Plant Biol. 2018, 69, 707-731. [CrossRef] [PubMed]

12. Greiner, S.; Rauwolf, U.; Meurer, J.; Herrmann, R.G. The role of plastids in plant speciation. Mol. Ecol. 2011, 20, 671-691. [CrossRef] [PubMed]

13. Burton, R.S.; Pereira, R.J.; Barreto, F.S. Cytonuclear genomic interactions and hybrid breakdown. Ann. Rev. Ecol. Evol. Syst. 2013, 44, 281-302. [CrossRef]

14. Stubbe, W. Genetische Analyse des Zusammenwirkens von Genom und Plastom bei Oenothera. Zeitschrift für Vererbungslehre 1959, 90, 288-298.

15. Stubbe, W. Extrem disharmonische Genom-Plastom-Kombinationen und väterliche Plastidenvererbung bei Oenothera. Zeitschrift für Vererbungslehre 1963, 94, 392-411. [CrossRef]

16. Stubbe, W. Oenothera-An ideal system for studying the interaction of genome and plastome. Plant Mol. Biol. Report. 1989, 7, 245-257. [CrossRef]

17. Schötz, F. Periodische Ausbleichungserscheinungen des Laubes bei Oenothera. Planta 1958, 52, 351-392. [CrossRef]

18. Stubbe, W.; Steiner, E. Inactivation of pollen and other effects of genome-plastome incompatibility in Oenothera. Plant Syst. Evol. 1999, 217, 259-277. [CrossRef]

19. Glick, R.; Sears, B.B. Genetically-programmed chloroplast dedifferentiation as a consequence of plastome-genome incompatibility in Oenothera. Plant Physiol. 1994, 106, 367-373. [CrossRef]

20. Dauborn, B.; Brüggemann, W. Genome and plastome effects on photosynthesis parameters in Oenothera species of differential low-temperature tolerance. Physiol. Plant. 1996, 97, 79-84. [CrossRef]

21. Chapman, M.J.; Mulcahy, D.L. Effect of genome-plastome interaction on meiosis and pollen development in Oenothera species and hybrids. Sex. Plant Reprod. 1997, 10, 288-292. [CrossRef]

22. Yao, J.L.; Cohen, D.; Rowland, R.E. Plastid DNA inheritance and plastome-genome incompatibility in interspecific hybrids of Zantedeschia (Araceae). Theor. Appl. Genet. 1994, 88, 255-260. [CrossRef] [PubMed]

23. Yao, J.-L.; Cohen, D. Multiple gene control of plastome-genome incompatibility and plastid DNA inheritance in interspecific hybrids of Zantedeschia. Theor. Appl. Genet. 2000, 101, 400-406. [CrossRef]

24. Mráček, J. Investigation of genome-plastome incompatibility in Oenothera and Passiflora. Ph.D. Thesis, Ludwig-Maximilians-University, Munich, Germany, 2005.

25. Kushnir, S.; Schlumukov, L.R.; Pogrebnyak, N.J.; Berger, S.; Gleba, Y. Functional cybrid plants possessing a Nicotiana genome and an Atropa plastome. Mol. Gen. Genet. 1987, 209, 159-163. [CrossRef] [PubMed]

26. Kushnir, S.; Babiychuk, E.; Bannikova, M.; Momot, V.; Komarnitsky, I.; Cherep, N.; Gleba, Y. Nucleo-cytoplasmic incompatibility in cybrid plants possessing an Atropa genome and a Nicotiana plastome. Mol. Gen. Genet. 1991, 225, 225-230. [CrossRef] [PubMed]

27. Thanh, N.D.; Medgyesy, P. Limited chloroplast gene transfer via recombination overcomes plastome-genome incompatibility between Nicotiana tabacum and Solanum tuberosum. Plant Mol. Biol. 1989, 12, 87-93. [CrossRef]

28. Perl, A.; Aviv, D.; Galun, E. Nuclear-organelle interaction in Solanum: Interspecific cybridizations and their correlation with a plastome dendrogram. Mol. Gen. Genet. 1991, 228, 193-200. [CrossRef]

29. Babiychuk, E.; Schantz, R.; Cherep, N.; Weil, J.-H.; Gleba, Y.; Kushnir, S. Alterations in chlorophyll a/b binding proteins in Solanaceae cybrids. Mol. Gen. Genet. 1995, 249, 648-654. [CrossRef]

30. Zubko, M.K.; Zubko, E.I.; Patskovsky, Y.V.; Khvedynich, O.A.; Fisahn, J.; Gleba, Y.; Schieder, O. Novel 'homeotic' CMS patterns generated in Nicotiana via cybridization with Hyoscyamus and Scopolia. J. Exp. Bot. 1996, 47, 1101-1110. [CrossRef]

31. Zubko, M.K.; Zubko, E.I.; Ruban, A.V.; Adler, K.; Mock, H.P.; Misera, S.; Gleba, Y.Y.; Grimm, B. Extensive developmental and metabolic alterations in cybrids Nicotiana tabacum (+Hyoscyamus niger) are caused by complex nucleo-cytoplasmic incompatibility. Plant J. 2001, 25, 627-639. [CrossRef]

32. Zubko, M.K.; Zubko, E.I.; Gleba, Y. Self-fertile cybrids Nicotiana tabacum (+Hyoscyamus aureus) with a nucleo-plastome incompatibility. Theor. Appl. Genet. 2002, 105, 822-828. [CrossRef] [PubMed]

33. Peter, S.; Spang, A.; Medgyesy, P.; Schäfer, C. Consequences of intergeneric chloroplast transfers on photosynthesis and sensitivity to high light. Aust. J. Plant Physiol. 1999, 26, 171-177. [CrossRef]

34. Herrmann, R.G.; Maier, R.M.; Schmitz-Linneweber, C. Eukaryotic genome evolution: Rearrangement and coevolution of compartmentalized genetic information. Philos. Trans. R. Soc. Lond. Ser. B Biol. Sci. 2003, 358, 87-97. [CrossRef] [PubMed] 
35. Bogdanova, V.S.; Berdnikov, V.A. Observation of the phenomenon resembling hybrid dysgenesis in a wild pea subspecies Pisum sativum ssp. elatius. Pisum Genet 2001, 33, 5-8.

36. Bogdanova, V.S.; Galieva, E.R. Meiotic abnormalities as expression of nuclear-Cytoplasmic incompatibility in crosses of Pisum sativum subspecies. Russ. J. Genet. 2009, 45, 623-627. [CrossRef]

37. Bogdanova, V.S.; Kosterin, O.E. A case of anomalous chloroplast inheritance in crosses of garden pea involving an accession of wild subspecies. Dokl. Biol. Sci. 2006, 406, 44-46. [CrossRef]

38. Bogdanova, V.S. Inheritance of organelle DNA markers in a pea cross associated with nuclear-cytoplasmic incompatibility. Theor. Appl. Genet. 2007, 114, 333-339. [CrossRef]

39. Martin, H.; Touzet, P.; Dufay, M.; Godé, C.; Schmitt, E.; Lahiani, E.; Delph, L.F.; Van Rossum, F. Lineages of Silene nutans developed rapid, strong, asymmetric postzygotic reproductive isolation in allopatry. Evolution 2017, 71, 1519-1531. [CrossRef]

40. Barnard-Kubow, K.B.; Galloway, L.F. Variation in reproductive isolation across a species range. Ecol. Evol. 2017, 7, 9347-9357. [CrossRef]

41. Kihara, H. Substitution of nucleus and its effects on genome manifestations. Cytologia 1951, 16, 177-193. [CrossRef]

42. Tsunewaki, K. Genome-plasmon interactions in wheat. Jpn. J. Genet. 1993, 68, 1-34. [CrossRef]

43. Tsunewaki, K.; Wang, G.-Z.; Matsuoka, Y. Plasmon analysis of Triticum (wheat) and Aegilops. 1. Production of alloplasmic common wheats and their fertilities. Genes Genet. Syst. 1996, 71, 293-311. [CrossRef] [PubMed]

44. Mukai, Y.; Tsunewaki, K. Genetic diversity of the cytoplasm in Triticum and Aegilops. IV. Distribution of the cytoplasm inducing variegation in common wheat. Theor. Appl. Genet. 1976, 48, 9-16. [CrossRef] [PubMed]

45. Ohtsuka, I. Genetic differentiation in wheat genomes in relation to compatibility with Aegilops squarrosa cytoplasm and application to phylogeny of polyploid wheats. J. Fac. Agric. Hokkaido Univ. 1991, 65, 127-198.

46. Simons, K.J.; Gehlhar, S.B.; Maan, S.S.; Kianian, S.F. Detailed mapping of the species cytoplasm-specific (scs) gene in durum wheat. Genetics 2003, 165, 2129-2136. [PubMed]

47. Sinyavskaya, M.G.; Danilenko, N.G.; Davydenko, O.G.; Ermishina, N.M.; Belko, N.B.; Gordey, I.A. Inheritance of organelle DNA in rye (Secale cereale L.) with triticale (Triticale Thch.) hybrids. Russ. J. Genet. 2004, 40, 160-164. [CrossRef]

48. Aksyonova, E.; Sinyavskaya, M.; Danilenko, N.; Pershina, L.; Nakamura, C.; Davydenko, O. Heteroplasmy and paternally oriented shift of the organellar DNA composition in barley-wheat hybrids during backcrosses with wheat parents. Genome 2005, 48, 761-769. [CrossRef]

49. Crosatti, C.; Quansah, L.; Maré, C.; Giusti, L.; Roncaglia, E.; Atienza, S.G.; Cattivelli, L.; Fait, A. Cytoplasmic genome substitution in wheat affects the nuclear-cytoplasmic cross-talk leading to transcript and metabolite alterations. BMC Genom. 2013, 14, 868. [CrossRef]

50. Pershina, L.A.; Trubacheva, N.V.; Sinyavskaya, M.G.; Devyatkina, E.P.; Kravtsova, L.A. Nuclear-cytoplasmic compatibility and the state of mitochondrial and chloroplast DNA regions in alloplasmic recombinant and introgressive lines (H. vulgare)-T. aestivum. Russ. J. Genet. 2014, 50, 1017-1024. [CrossRef]

51. Lilienfeld, F.A. Plastid behavior in reciprocally different crosses between two races of Medicago truncatula Gaertn. Seiken Ziho 1962, 13, 3-38.

52. Matsushima, R.; Hu, Y.; Toyoda, K.; Sodmergen; Sakamoto, W. The model plant Medicago truncatula exhibits biparental plastid inheritance. Plant Cell Physiol. 2008, 49, 81-91. [CrossRef] [PubMed]

53. Lilienfeld, F.A. A case of malfunctioning plastids in Medicago truncatula Gaertn. Jpn. J. Genet. 1965, 40, 261-274. [CrossRef]

54. Moffett, A.A. Genetical studies in Acacias. I. The estimation of natural crossing in black wattles. Heredity 1956, 10, 57-67. [CrossRef]

55. Moffett, A.A. Genetical studies in Acacias. III. Chlorosis studies in interspecific hybrids. Heredity 1965, 20, 609-620. [CrossRef]

56. Renner, O. Zur Kenntniss des Pollenkompelxes flectens der Oenothera atrovirens Sh. et Bartl. Zeitschrift für induktive Abstammungs-und Vererbungslehre 1943, 81, 391-483. [CrossRef]

57. Rauwolf, U.; Golczyk, H.; Meurer, J.; Herrmann, R.G.; Greiner, S. Molecular marker systems for Oenothera genetics. Genetics 2008, 180, 1289-1306. [CrossRef]

58. Stinson, H.T. Extranuclear barriers to interspecific hybridization between Oenothera hookeri and Oenothera argillicola. Genetics 1960, 45, 819-839. 
59. Van der Meer, J.P. Hybrid chlorosis in interspecific crosses of Oenothera: Polygenic inheritance of the nuclear component. Can. J. Genet. Cytol. 1974, 16, 193-201. [CrossRef]

60. Rauwolf, U. Mapping of Genomes and Plastomes of Subsection Oenothera with Molecular Marker Technologies. Ph.D. Thesis, Ludwig-Maximilians-University, Munich, Germany, 2008.

61. Yao, J.L.; Cohen, D.; Rowland, R.E. Interspecific albino and variegated hybrids in the genus Zantedeschia. Plant Sci. 1995, 109, 199-206. [CrossRef]

62. Ureshino, K.; Abe, T.; Akabane, M. Relationship between nuclear genome construction and the plastome-genome incompatibility of progenies from intra- and inter-ploid cross of evergreen azaleas $\times$ Rhododendron japonicum f. flavum. J. Jpn. Soc. Hortic. Sci. 2010, 79, 91-96. [CrossRef]

63. Ureshino, K.; Miyajima, I.; Ozaki, Y.; Kobayashi, N.; Michishita, A.; Akabane, M. Appearance of albino seedlings and ptDNA inheritance in interspecific hybrids of azalea. Euphytica 1999, 110, 61-66. [CrossRef]

64. Anderson, J.A.; Maan, S.S. Interspecific nuclear-cytoplasmic compatibility controlled by genes on group 1 chromosomes in durum wheat. Genome 1995, 38, 803-808. [CrossRef] [PubMed]

65. Asakura, N.; Nakamura, C.; Ohtsuka, I. RAPD markers linked to the nuclear gene from Triticum timopheevii that confers compatibility with Aegilops squarrosa cytoplasm on alloplasmic durum wheat. Genome 1997, 40, 201-210. [CrossRef] [PubMed]

66. Asakura, N.; Nakamura, C.; Ohtsuka, I. A nuclear compatibility gene, Ncc-tmp, of Triticum timopheevii for the cytoplasm of Aegilops squarrosa. Genes Genet. Syst. 1997, 72, 71-78. [CrossRef]

67. Asakura, N.; Nakamura, C.; Ohtsuka, I. Homoeoallelic gene Ncc-tmp of Triticum timopheevii conferring compatibility with thecytoplasm of Aegilops squarrosa in the tetraploid wheat nuclear background. Genome 2000, 43, 503-511. [CrossRef]

68. Murata, M.; Nakata, N.; Yasumuro, Y. Origin and molecular structure of a midget chromosome in a common wheat carrying rye cytoplasm. Chromosoma 1992, 102, 27-31. [CrossRef]

69. Suzuki, T.; Nakamura, C.; Mori, N.; Iwasa, Y.; Kaneda, C. Homoeologous group I chromosomes of Agropyron restore nucleus-cytoplasmic compatibility in alloplasmic common wheat with Agropyron cytoplasms. Jpn. J. Genet. 1994, 69, 41-51. [CrossRef]

70. Jiang, J.W.; Raupp, J.; Gill, B.S. $R f$ genes restore fertility in wheat lines with cytoplasms of Elymus trachycaulus and E. ciliaris. Genome 1992, 35, 614-620. [CrossRef]

71. Maan, S. Transfer of a species cytoplasm specific (scs) gene of Triticum timopheevii Zhuk to T. Turgidum. Genome 1992, 35, 238-243. [CrossRef]

72. Maan, S. The sCs and Vi genes correct a syndrome of cytoplasmic effects in alloplasmic durum wheat. Genome 1992, 35, 780-787. [CrossRef]

73. Maan, S. A gene for embryo-endosperm compatibility and seed viability in alloplasmic Triticum turgidum. Genome 1992, 35, 772-779. [CrossRef]

74. Seth, K. High Resolution Mapping of the $s c s^{t i}$ Gene in Durum Wheat and Conserved Colinearity Across Three Grass Genomes: Wheat, Rice and Brachypodium. Ph.D. Thesis, North Dakota State University, Fargo, ND, USA, 2009.

75. Hossain, K.G.; Riera-Lizarazu, O.; Kalavacharla, V.; Vales, M.I.; Maan, S.S.; Kianian, S.F. Radiation hybrid mapping of the species cytoplasm-specific $\left(s c s^{a e}\right)$ gene in wheat. Genetics 2004, 168, 415-423. [CrossRef] [PubMed]

76. Hossain, K.G.; Riera-Lizarazu, O.; Kalavacharla, V.; Vales, M.I.; Rust, J.L.; Maan, S.S.; Kianian, S.F. Molecular cytogenetic characterization of an alloplasmic durum wheat line with a portion of chromosome 1D of Triticum aestivum carrying the scs $^{a e}$ gene. Genome 2004, 47, 206-214. [CrossRef] [PubMed]

77. Michalak de Jimenez, M.K.; Bassi, F.M.; Ghavami, F.; Simons, K.; Dizon, R.; Seetan, R.I.; Alnemer, L.M.; Denton, A.M.; Doğramac1, M.; Šimková, H.; et al. A radiation hybrid map of chromosome 1D reveals synteny conservation at a wheat speciation locus. Funct. Integr. Genom. 2013, 13, 19-32. [CrossRef]

78. Bogdanova, V.S.; Galieva, E.R.; Kosterin, O.E. Genetic analysis of nuclear-cytoplasmic incompatibility in pea associated with cytoplasm of an accession of wild subspecies Pisum sativum subsp. elatius (Bieb.) Schmahlh. Theor. Appl. Genet. 2009, 118, 801-809. [CrossRef]

79. Bogdanova, V.S.; Galieva, E.R.; Yadrikhinskiy, A.K.; Kosterin, O.E. Inheritance and genetic mapping of two nuclear genes involved in nuclear-cytoplasmic incompatibility in peas (Pisum sativum L.). Theor. Appl. Genet. 2012, 124, 1503-1512. [CrossRef] 
80. Boffey, S.A.; Leech, R.M. Chloroplast DNA levels and the control of chloroplast division in light-grown wheat leaves. Plant Physiol. 1982, 69, 1387-1391. [CrossRef]

81. Gu, K.; Chiam, H.; Tian, D.; Yin, Z. Molecular cloning and expression of heteromeric ACCase subunit genes from Jatropha curcas. Plant Sci. 2011, 180, 642-649. [CrossRef]

82. Schmitz-Linneweber, C.; Kushnir, S.; Babiychuk, E.; Poltnigg, P.; Herrmann, R.G.; Maier, R.M. Pigment deficiency in nightshade/tobacco cybrids is caused by the failure to edit the plastid ATPase alpha-subunit mRNA. Plant Cell 2005, 17, 1815-1828. [CrossRef]

83. Schmitz-Linneweber, C.; Regel, R.; Du, T.G.; Hupfer, H.; Herrmann, R.G.; Maier, R.M. The plastid chromosome of Atropa belladonna and its comparison with that of Nicotiana tabacum: The role of RNA editing in generating divergence in the process of plant speciation. Mol. Biol. Evol. 2002, 19, 1602-1612. [CrossRef]

84. Bock, R. Sense from nonsense: How the genetic information of chloroplasts is altered by RNA editing. Biochimie 2000, 82, 549-557. [CrossRef]

85. Loiacono, F.V.; Thiele, W.; Schöttler, M.A.; Tillich, M.; Bock, R. Establishment of a Heterologous RNA Editing Event in Chloroplasts. Plant Physiol. 2019, 181, 891-900. [CrossRef] [PubMed]

86. Greiner, S.; Wang, X.; Rauwolf, U.; Silber, M.V.; Mayer, K.; Meurer, J.; Habere, G.; Herrmann, R.G. The complete nucleotide sequences of the five genetically distinct plastid genomes of Oenothera, subsection Oenothera: I. Sequence evaluation and plastome evolution. Nucl. Acids Res. 2008, 36, 2366-2378. [CrossRef] [PubMed]

87. Greiner, S.; Wang, X.; Herrmann, R.G.; Rauwolf, U.; Mayer, K.; Haberer, G.; Meurer, J. The complete nucleotide sequences of the 5 genetically distinct plastid genomes of Oenothera, subsection Oenothera: II. A microevolutionary view using bioinformatics and formal genetic data. Mol. Biol. Evol. 2008, 25, 2019-2030. [CrossRef] [PubMed]

88. Burrows, P.A.; Sazanov, L.A.; Svab, Z.; Maliga, P.; Nixon, P.J. Identification of a functional respiratory complex in chloroplasts through analysis of tobacco mutants containing disrupted plastid $n d h$ genes. EMBO J. 1998, 17, 868-876. [CrossRef] [PubMed]

89. Kofer, W.; Koop, H.U.; Wanner, G.; Steinmüller, K. Mutagenesis of the genes encoding subunits A, C, H, I, J and $\mathrm{K}$ of the plastid $\mathrm{NAD}(\mathrm{P}) \mathrm{H}$-plastoquinone-oxidoreductase in tobacco by polyethylene glycol-mediated plastome transformation. Mol. Gen. Genet. 1998, 258, 166-173. [CrossRef] [PubMed]

90. Kaló, P.; Seres, A.; Taylor, S.A.; Jakab, J.; Kevei, Z.; Kereszt, A.; Endre, G.; Ellis, T.H.; Kiss, G.B. Comparative mapping between Medicago sativa and Pisum sativum. Mol. Genet. Genom. 2004, 272, 235-246. [CrossRef]

91. Bogdanova, V.S.; Zaytseva, O.O.; Mglinets, A.V.; Shatskaya, N.V.; Kosterin, O.E.; Vasiliev, G.V. Nuclear-cytoplasmic conflict in pea (Pisum sativum L.) is associated with nuclear and plastidic candidate genes encoding acetyl-CoA carboxylase subunits. PLoS ONE 2015, 10, e0119835. [CrossRef]

92. Nováková, E.; Zablatzká, L.; Brus, J.; Nesrstová, V.; Hanáček, P.; Kalendar, R.; Cvrčková, F.; Majeský, L'.; Smýkal, P. Allelic diversity of acetyl coenzyme A carboxylase accD/bccp genes implicated in nuclear-cytoplasmic conflict in the wild and domesticated pea (Pisum sp.). Int. J. Mol. Sci. 2019, 20, 1773. [CrossRef]

93. Bassi, F.M.; Ghavami, F.; Hayden, M.J.; Wang, Y.; Forrest, K.L.; Kong, S.; Dizon, R.; Michalak de Jimenez, M.K.; Meinhardt, S.W.; Mergoum, M.; et al. Fast-forward genetics by radiation hybrids to saturate the locus regulating nuclear-cytoplasmic compatibility in Triticum. Plant Biotechnol. J. 2016, 14, 1716-1726. [CrossRef]

94. Jeyaraju, D.V.; Sood, A.; Laforce-Lavoie, A.; Pellegrini, L. Rhomboid proteases in mitochondria and plastids: Keeping organelles in shape. Biochim. Biophys. Acta 2013, 1833, 371-380. [CrossRef] [PubMed]

95. Adam, Z. Plastid intramembrane proteolysis. Biochim. Biophys. Acta 2015, 1847, 910-914. [CrossRef] [PubMed]

96. Yeates, A.M.; Zubko, M.K.; Ruban, A.V. Absence of photosynthetic state transitions in alien chloroplasts. Planta 2019, 250, 589-601. [CrossRef] [PubMed]

97. Rockenbach, K.; Havird, J.C.; Monroe, J.G.; Triant, D.A.; Taylor, D.R.; Sloan, D.B. Positive selection in rapidly evolving plastid-nuclear enzyme complexes. Genetics 2016, 204, 1507-1522. [CrossRef] [PubMed] 
98. Zhang, J.; Ruhlman, T.A.; Sabir, J.; Blazier, J.C.; Jansen, R.K. Coordinated rates of evolution between interacting plastid and nuclear genes in Geraniaceae. Plant Cell 2015, 27, 563-573. [CrossRef] [PubMed]

99. Weng, M.L.; Ruhlman, T.A.; Jansen, R.K. Plastid-Nuclear Interaction and Accelerated Coevolution in Plastid Ribosomal Genes in Geraniaceae. Genome Biol. Evol. 2016, 8, 1824-1838. [CrossRef]

(C) 2019 by the author. Licensee MDPI, Basel, Switzerland. This article is an open access article distributed under the terms and conditions of the Creative Commons Attribution (CC BY) license (http://creativecommons.org/licenses/by/4.0/). 